\title{
'TINA', aids, and the underdevelopment problem in Africa
}

\author{
AKINPELU OLANREWAJU OLUTAYO \\ MOLATOKUNBO ABIOLA OLUWASEUN OLUTAYO \\ AYOKUNLE OLUMUYIWA OMOBOWALE*
}

The assumption that 'There Is No Alternative' (TINA) to capitalism as practiced in the United States of America and Western Europe has been the bane of aids effectiveness in assisting to solve the underdevelopment problem in Africa. This paper attempts to show that except there is a fundamental reorientation in the conceptualization of capitalism-free market and democracythe underdevelopment problem would only be further complicated with aids.

Keywords 'TINA'; Dependency; Underdevelopment; Aids; Africa.

JEL Classification: FO2.

Africa is the world's second-largest and second most populous continent, after Asia, accounting for more than $12 \%$ of the world's human population (http://en.wikipedia.org/wiki/Africa). Africa is home to the oldest inhabited territory on earth, with the human race originating from this continent. It is not, therefore, the evolution of ape-like humans to modern day man that makes Africa's contribution to world civilization unique but that civilization originated from Africa (Bernal, 1991). That the art of writing emerged from Egypt is not more important than the fact that other prominent civilizations in Ethiopia, Zimbabwe, Oyo, Ghana, Mali, Songhai, and so on, emerged in Africa even before the dominance of Roman and Greek civilizations. In other words, the peoples of Africa

\footnotetext{
* Respectivelly, Department of Sociology, Faculty of the Social Sciences, University of Ibadan, Ibadan, Nigeria, e-mail: lantopamtu@yahoo.com; Department of Political Sciences, Faculty of Social Sciences, Olabisi Onabanjo University, Ago-Iwoye, Nigeria, e-mail: lantopamtu@yahoo.com; Department of Sociology, University of Lagos, Akoka, Lagos, e-mail: muyiwaking@yahoo.com. Submitted: July 2006; Accepted: December 2006.
} 
had developed ways of exploiting their environment, used same to satisfy their wants and needs, and had created institutions around these survival techniques ever before 1482 when the Portuguese established the first trading port along the coast of Elmina. Thus, began the re-orientation of the African continent to external needs within which the economic and political institutions became subordinated to European influence.

In the early nineteenth century, the scramble for Africa by European imperial powers brought an end to independent development in Africa. Within half a century, all of Africa was mapped, explored, estimated and divided between the European powers with little or no cognizance taken of the welfare of the peoples (http://www.bartleby.com/86/62.html). By the quarter of a century, Africa was partitioned for different European interests. Colonial capitalism had taken over on the world scale and everything had to be defined from the perspective of the colonizing nations. Even the so called 'formal independence' was based on the latter's terms such that the borders of almost all the independent African nations were the creations of European colonialism. Indeed, whatever is defined as underdevelopment today are results of colonial legacies. The Second World War in Europe, the creation of 'new elites', inter-and intra-ethnic rivalries, military coups and counter-coups, the Cold War, the collapse of the Berlin Wall, the triumph of capitalism over socialism and so on, were (and still are) the issues that created Africa. In its incorporation into the World Capitalist System through colonialism, and the beginning of the underdevelopment process-wherein 'old' civilizations were subordinated to the 'new' - the former is now characterized by what it lacks but is present in the latter. Development is now defined for former colonial territories based on their ability to ape their former colonizers.

With the emergence of profit-making corporations since the seventeenth century Europe, and with the imperial backing in the creation of colonial companies, the economic subordination of Africa, like its Asian and American counterparts, began. The colonial companies, with its own private armies, were used to finance colonial expansions, and to maintain draconian control of trade, resources, and territories (New Internationist, 2002). With the American Revolutionary War for independence in 1776, free-trade became the new norm and, by the end of the nineteenth century, 'unchecked capitalism', in the words of the New Internationalist (ibid.), ran rampant thus leading to state interventions in Europe and the United States of America - especially due to the depressions of the 1930s, the World War II, and the protests within these nations. In broad outlines, this informed the policy of state intervention in the African colonies. Today, however, 'unchecked capitalism' is the expected 'new norm' even when conditions do not seem favorable! But what has the story been so far? Before delving to this 'story', we briefly explain the theoretical framework within which our analyses hinge. 


\section{DEPENDENCY THEORY}

This paper is analyzed within the framework of dependency theory initiated by Paul Baran's (1957) The Political Economy of Growth and which has been expounded in various ways. This exposition is more in terms of using various terminologies rather than limiting certain terms to academic spheres. Basically, the theorists tend to identify the same reason for underdevelopment in the less developed nations. This is the World Capitalist System. Within this perspective, it is posited that the incorporation of the less developed nations into the World Capitalist System explains the reason(s) for their underdevelopment status. The World Capitalist System, it is argued, conditions the economies of these nations and makes them subservient to and 'dependent' on the system. Thus, an understanding of the less developed nations' position cannot be clear without taking the 'external factor' into consideration. It is this factor that explains the economic, political and social structures of the less developed nations. Hence, the effect of colonialism on the Third World Nations is given prominence. According to Frank (1984), it is what brought about underdevelopment.

To dependency theorists, development for the underdeveloped is impossible within this World Capitalist arrangement for the underdeveloped nations. It is only within the socialist arrangement that development can be possible (Frank, 1967; Wallerstein, 1980; Furtado, 1970). Explaining why this is not possible, Frank (1972), using Baran's concept of economic surplus, uses the concepts of 'metropolis-centre' and 'peripheral-satellite'. He shows how the 'chains of dependency' from the most advanced societies to the most rural parts of Latin America are linked through the expropriation/appropriation of economic surplus from the latter by the former. In this process, the social, political and economic structures of Latin America were determined. This led to the polarization of the metropolis and the satellite nations in which case the expropriation of surplus to the metropolis led to its development while the expropriated satellite nations became underdeveloped. The situation arose because the political elites-created through the incorporation of the Third World nations into the World Capitalist System - were conditioned to suit the purposes of the metropolitan bourgeoisie. Thus, their interests became linked together. For Frank, and others, therefore, development cannot be achieved through the political elites in the underdeveloped nations. It requires the struggle of the exploited people within these national satellites to bring about socialist arrangement.

In spite of its inadequacies, this perspective has been largely commended on its appreciation of the negative effect of the international economy on the societies of the Third World (O'Brien, 1975). It has shifted emphasis from the 'traditionmodern' continuum as a means of explaining change. Furthermore, it laid another starting point from which the analysis of development and underdevelopment should be viewed. In addition, it has enriched what it called the "simplistic" 
Marxist views on the likely effects of capitalist expansion in the underdeveloped countries. It used a "revised Marxist methodology" to stress the interplay between the internal and external structures. On the other hand, classical Marxist were criticized for viewing the expansion of capitalism into underdeveloped countries as simply a process of destruction and replacement of pre-capitalist structures. These processes were set in motion through a deliberate policy of colonization, some of which we briefly elaborate in the 'story' for the African situation below.

\section{COLONIAL DEVELOPMENT AND WELFARE ACT AND THE DEBT PROBLEM}

Though the missionaries were largely in charge of education through which they intended to convert Africans from their 'uncivilized' tradition and 'uncultured', 'undisciplined paganism' (Schivji, 2005) to European religion of Christianity and European ways of life (the famous Bible and the Plough doctrine) (Olutayo, 1991), the Colonial Development and Welfare Act introduced direct state intervention in education. This policy marked the beginning of a new underdevelopment process wherein conscious efforts were made by the colonial governments to spur economic development through the provision of infrastructures. In the words of Pool (2002), 'British colonial officials came to believe that improving the educational, social, medical, and economic infrastructure of its colonies would lay a foundation for increased African participation in colonial administration'. This laid the foundation for the creation of 'new elite' that would take over from them. It was also, for Nigeria, and indeed most of Africa, the beginning of the debt-burden (Falola, 1996). Starting with the one million pound per year in the 1920s, it was increased to five million pounds per year in the 1940 and to one hundred and twenty million in 1945 (Barder, 2005).

By 1947, the Overseas Development Act established the Colonial Development Corporation to operate in the colonies and the Overseas Development Corporation for the whole world. These were the first systematic aid programs to be operated by the United Kingdom with some consideration for the recipient country even though the idea of 'development' was West-Euro-centred. Not surprisingly therefore, the emergence of the Soviet Union threatened Western Europe's conception of development and it became clear that aid was not 'morality' bound but 'to encourage trade'. Indeed, with the establishment of the Development Assistance Committee in 1960, chaired by the United State's (US) ambassadors up till 1999, the ideology of free trade as the ultimate aim came to the fore.

Development plans, which started since the 1940s, were invigorated. These plans were to be under the 'technical' assistance from Europe and the US. Thus began the emergence of 'development experts' or who Branford and Kucinski 
(1989) referred to as the 'debt squads'. As Macdonald has shown, the French also fully embraced the idea of economic development assistance after the World War II. Associated with this economic aid was the French policy of maintaining tight political and economic control over the colonies through, among others, centralized currency regulation and limited access to political and educational institutions. The need to cope with high expectations of newly independent nations by the 1960s witnessed increased French foreign aid assistance to West Africa. This grew to 1.4 percent of France's gross national product - twice the current UN target for aid from the industrialized countries and four times the present US level.

Paradoxically, these also became the 'apostolic' basis of 'development plans', undertaken by the newly created elite. As such, as the indigenous social structures were undermined, the need for loans and aids also became justified on the basis of new development' orientations. What used to be conceptualized as 'education', 'medicine', 'economic', 'politics', 'poverty', and so on, changed.

In short, development was no longer seen as the ability to independently determine what a nation desired but defined by those 'external' to that environment. This was not, unsurprisingly, essentially different from the 'nationalists' orientation in their development plans! Not surprising because they were 'schooled' in the 'colonialists' educational institutions and were, more or less, competing with the indigenous elite who had been prominent before and during colonial intervention. As such, those on whom governance devolved had to operate 'developmentalism' reflected in the creation of public property (Hutchful, 2002) and the distribution of political patronage to local chiefs so as to hold national alliances (Lockwood, n.d.). What is thus characterized as underdevelopment is based on conceptions that emerged with the incorporation of Africa into 'other' economies. In these terms therefore, Africa assumed the image of the 'White Man's Burden' even though, in the final analysis, the amount of resources Africa pumps to the North-occupied by the 'whites'- is enormous (Bond, 2005).

\section{AFRICA IN WORLD IMAGE, AIDS AND THE DONORS' RECOMMENDATIONS}

Independence from colonialism was expected to, genuinely; create nations that could do their own things their own way. On the contrary, the dependency seemed to continue, especially, or, perhaps, in spite of the socialist regime in the world economy! African leaders who attempted the socialist alternative also couched their ideas within 'imported' perspective neglecting the indigenous/ traditional elite dominating the 'rural' areas. By 1962, Africa was already "in a sorry state” (Draft Concept Paper of the African Union, 2004). 
The description of Africa being "in a sorry state" is not unconnected to the Western perception of Africa with roots in the colonial era. Such perception expects the African to see herself as 'unworthy' and all her ways of life, including speech, to be in terms of the 'other' - Western. To be 'urbanized', 'modernized', 'developed' and so on, are defined in Western terms - a position corroborated by the United Nations' agencies. In his analysis Helmeth (2005), focusing on American textbooks for Geography, the media in the UK and the USA, and international agencies such as United States Agency for International Development (USAID) and BMZ (German Federal Ministry for Cooperation and Development), found that 'the term 'poverty' is defined by the non-poor so that one has to be skeptical when people are classified as 'poor'. As such, the indices used to measure do not examine the underlying actual problems. BMZ, he observes, links development with increasing possibilities for individuals to choose and act freely in order to improve their conditions of life. The international agencies, such as the UK's Department for International Development (DFID) and the USAID have 'twofold purpose of furthering [...] foreign policy interests in expanding democracy and the free market [...]' (http://www.usaid.gov/aboutusaid; see also http://www. dfid.gov.uk/aboutdfid/). It is not surprising, therefore, that the discussions so far about Africa's development are focused around the creation of free-market and the institutionalization of democratic ethos.

This is the crux for which alternative has not been found. Yet, this is the contradiction in aids. Must aids be given only under the conditions of free-market and democracy? Well, this is not surprising since Africa is only to be kept safe from terrorists as security in donor countries has become an important condition for giving aid. Poverty, as Mair (2003) distills, from other authors, is the main cause of terrorism. And this is why, perhaps, the US places significant emphasis on Afghanistan, Iraq and Sudan (Condoleezza Rice, 2006). More important, however, is the fact that the donor countries perceive that 'in changing people's lives, in alleviating poverty, in creating the conditions for stable and well-governed states around the world, and in doing so in enhances (sic) America's security and America's compassion' (Condoleezza Rice, 2006), the world would be safe.

Succinctly put, Africa's image is that of a poor continent lacking economic perspectives, characterized of social deprivation, political repression and dysfunctional states as well as lacking cultural identity (Mair, op. cit). These characteristics make Africa prone to terrorism and, as such, in need of aid. This image is in spite of the realization of the effects of globalization on Africa. While authors, agencies and governments acknowledge these facts, the recommendation has always been 'more dosage' of these 'drugs'! What is required for the donor agencies is to develop better 'coherent policies and effective programs' and the recipients to accelerate change in governance by creating the 'right economic, social and legal framework which will encourage economic growth and allow poor people to participate in it' (Commission for Africa, p. 10). These entail 
horticulture agriculture; private sector-led economy; and the government to merely provide the 'enabling environment' by ensuring independent judiciary; providing security and protection of basic rights; effective policing; effective financial and regulatory systems in central banking, land registry, border ports and coast posts as well as training and retraining the staff in these administrative roles. Until these are done, it is concluded, 'Africa will be doomed to continue its economic stagnation' (Commission for Africa, p. 11). It is, indeed, ensuring a more open economy from the recipients' side since, in the words of President Clinton, in 1997, "protectionism is simply not an option because globalization is irreversible" (cited in Boafo-Arthur, 2003) with no other alternative. Yet, according to his chairman of economic council of advisers for seven years, the 2001 Nobel Prize winner in economics, and the Chief economist at the World Bank, the International Monetary Fund (IMF) puts interest of its "larger shareholder, the US above those of poor nations"(Stiglitz, 2002).

It is not surprising, therefore, that even with the agreement that increased aid and debt cancellation are necessary for Africa to meet the Millennium Development Goals (MDGs), 'better governed countries'- in terms of being 'democratic, accountable and transparent' are conditional requirements (Drummond, 2006). Even at this, the December, 2005 World Trade Organization (WTO) Ministerial meeting ended with the rich countries, particularly the European Union and the US, being only interested in ensuring open markets from the developing nations in favor of their major corporations. They retained domestic agricultural subsidies that damage poor and vulnerable farmers in developing countries (Make Poverty History and the Trade Justice Movement http://www. makepovertyhistory.org/docs/MPH-wtoresponse.doc). In other words, freemarket is, as it had always been, an important pre-condition for aids. And, it seems to have been realized, access to free trade is most possible under democracytermed 'good' governance with respect to the donor countries. This was the process established since the colonial period, as shown above. Perhaps very clear from this is that one of the major reasons for Africa's 'sorry state' is the 'unequal exchange' founded on the 'others' development perspective.

\section{AFRICAN ALTERNATIVES TO DEVELOPMENT: CONCLUSION}

While recognizing the various concerns, especially of the international nongovernmental organizations' pressures on their governments, and the attempts to improve on the Millennium Development Goals, it is equally important to also acknowledge Africans' perspectives. Africans have provided various alternatives which the donor countries seem to have refused because it recommends, in the final instance, the independent development of Africa. Rather, the donors are 
only interested in 'scratching the surface' of the problem with 'aid assistance' even when such seem to further impoverish Africans (Munyemesha, 2003).

The African Alternative to Structural Adjustment Program for SocioEconomic Recovery (AAF-SAP)(1989) represents an important position while the African Charter for Popular Participation in Development and Transformation (1990) attempted to further clarify the AAF-SAP, the latter being an elaboration of the Lagos Plan of Action (1980). Without delving too much into the AAF-SAP, one can say that it has clearly shown that development needs to be conceived by the people and for the people through the establishment of independent grassroots organizations at various levels. These organizations are expected to be voluntary, democratically administered yet rooted in the tradition and culture of the people and self-reliant. While recognizing the importance of African and international governmental and non-governmental organizations, the idea of popular participation, the document posits, has to begin at the family and, by implication, the community level.

These, to us, are realizable when the people are economically independent. To ensure this, the people would need to redefine their survival through the exploitation of the environment without which it may be difficult to engage in the definition and production of their needs. This involves relearning indigenous survival techniques with a view to improve such. The communal and family levels in the rural areas are where these are most practicable and the assistance required from the government is to redesign the school curricula. In other words, the understanding of the environment and the creation of appropriate technologies are of fundamental importance to independent survival. This, within the various grassroots organizations, would have to involve an in-depth understanding of communal knowledge along with attempts at improving such through 'communal competitions'. With this the outcomes of such competitions become the 'people's property' for which they 'undertake sacrifices and expend social energies for its execution'. Where the people possess the economic power, their political emancipation is, more or less, certain. This is visible in the present dispensation where the rural people do not seem to be bothered about what happens at the political institutions. Where their economic survival is assured through these organizations, based on the creation of their means of survival, it is only a matter of time, we believe, before even their 'oppressors' realize that they are the ones who need them.

\section{REFERENCES}

African Alternatives Framework: An Alternative Framework to Structural Adjustment Programs http://server.africapolicy.org/african-initiatives/aaf4.htm ; http://server.africapolicy.org/africaninitiatives/aaf5.htm; http://server.africapolicy.org/african-initiatives/aaf6.htm accessed $27^{\text {th }}$ February, 2006 
BARAN, P. (1957) The Political Economy of Growth (New York: Monthly Review)

BARDER, O. (2005) 'Development Assistance: Lessons from the UK Experience' http://www.owen. org/file_Lessons_from_the_uk_Experience_WP_70.pdf accessed 15th December, 2005

BERNAL, M. (1991) Black Athena: The Afroasiatic Roots of Classical Civilization (New Jersey: Rutgers University Press) Vol. II

BOAFO-ARTHUR, K (2003) 'Tackling Africa's Developmental Dilemmas: Is Globalization the Answer?' Journal of Third World Studies, vol. $\mathrm{xx}, \mathrm{n}^{\circ} 1$

BOND, P. (2005) 'Dispossessing Africa's Wealth' http://www.globalpolicy.org/socecon/develop/africa/ 2005/1027disposs.htm.accessed 20th November, 2005

BRANFORD, S. and Kunciski, B (1989) The Debt Squads: The US, the Banks and Latin America (London: Zed Books).

Commission for Africa (2005) 'Analysis and Evidence' http://www.number-10.gov.uk/files/pdf/ Chapter\%201-final.pdf accessed 2nd February, 2006

Draft Concept Paper of the African Union (2004) http://www.africa-union.org/NEWS_Events/ Calendar_of_\%Events/Conference\%des\%20Intellectuals/Draft \%20Concept $\% 20$ Paper.pdf accessed $10^{\text {th }}$ November, 2005

DRUMMOND, J. (2006) G8 Leaders: Help Keep Our Promise to Africa's Poor http://www.data.org/ archives/000766.php accessed 20 $0^{\text {th }}$ February, 2006

Economic Commission for Africa (1989) African Alternative Framework to Structural Adjustment Programmes for Socio-Economic Recovery and Transformation E/ECA/CM. 15/6/Rev.3

FALOLA, T. (1999) Development Planning and Decolonization in Nigeria http://www.findarticles. com/P/articles/mi_qa3821/is_199904/ai_n8846832 accessed 22nd February, 2006.

FRANK, A. G.(1984) 'Development of Underdevelopment' in Wilber, C.K. (ed) The Political Economy of Underdevelopment ( New York: Random House)

FRANK, A. G. (1972) Lumpenbourgeoisie:Lumpendevelopment (New York: Monthly Review Press).

FRANK, A. G. (1969) Capitalism and Underdevelopment in Latin America (New York: Monthly Review Press)

FURTADO, C. (1970) Economic Development of Latin America: A Survey from Colonial Times to the Cuban Revolution (Cambridge: Cambridge University Press)

HELMETH, W. (2005) How are African States, especially sub-Saharan States, portrayed by the Western Community? http://www.africafiles.org/article.asp?ID=9277\&ThisURL=\&URLName accessed $15^{\text {th }}$ November, 2005

http://en.wikipedia.org/wiki/Africa Wikipedia-free online encyclopedia accessed $16^{\text {th }}$ January, 2005

http://www.bartleby.com/67/2559.html The Encyclopedia of World History Accessed on Feb 20, 2006.

http://www.dfid.gov.uk/aboutdfid/ About DFID Accessed on Jan 31, 2006

http://www.makepovertyhistory.org/docs/MPH-wtoresponse.doc MAKEPOVERTYHISTORY and the Trade Justice Movement statement on the World Trade Organisation (WTO) Ministerial meeting in Hong Kong (18 December 2005) Accessed on Feb 2, 2006.

http://www.usaid.gov/about_usaid/ This is USAID Accessed on Jan. 31, 2006

HUTCHFUL, E. (2002) Ghana's Adjustment Experience: The Paradox of Reform (Geneva: United Nations Research Institute for Social Development).

LOCKWOOD, M. (n.d) We must breed tigers in Africa http://www.guardian.co.uk/hearafrica05/story/ 0,15756,1513561,00.htm Accessed on Feb 2, 2006.

MACDONALD, L. H. A History of aid http://www.unu.edu/unupress/unupbooks/80422E04.htm\#2. $\% 20 \mathrm{~A} \% 20$ history\%20 of \%20aid accessed $15^{\text {th }}$ November 2005.

MAIR, S. (2003) 'Terrorism and Africa: On the danger of further attacks in sub-Saharan Africa" Security Review, vol. 12 (1).

MUNYEMESHA, E. (2003) 'International Aid' http://www.masternewmedia.org/2005/06/13/ foreign_aid_development_assistance_a.htm accessed $15^{\text {th }}$ November 2005

New Internationist (2002) A Short History of Corporations http://www.newint.org/issue347/ history. htm Accessed on Feb. 20, 2006. 
O'BRIEN, P. J. (1975) ‘A Critique of Latin American Theories of Dependency' in Oxaal, I., Barnett,T., and Booth, D. (eds) Beyond the Sociology of Development (London and Boston: Routledge and Kegan Paul)

OLUTAYO, A. O. (1991) 'The Development of underdevelopment: Rural Economy of Colonial Southwestern Nigeria' Unpublished Phd thesis submitted to the Department of Sociology, Faculty of the Social Sciences, University of Ibadan, Ibadan.

POOL, J. (2002) http://www.ecu.edu/african/sersas/Papers/PoolJeremy/Spring2002.htm accessed 20th February, 2006

RICE, C. (2006) Remarks by Condoleezza Rice, U.S. Secretary of State: New Directions for US Foreign Assistance http://www.usaid.gov/press/speeches/2006/sp060119.html accessed 20th February, 2006

SHIVJI, I. G. (2005) 'The Changing Development Discourse in Africa' in Yieke, F.A. ed East Africa: In Search of National and Regional Renewal (Dakar: CODESRIA).

STIGLITZ, J. E. (2002) Globalization and Its Discontent (Australia: Penguin Books).

WALLERSTEIN, I. (1980) The Capitalist World-Economy (Cambridge: Cambridge University Press). 